\title{
Kan vi stole på legemiddelindustrien?
}

Min allmennpraktiserende kollega Ingard Løge i Trondheim sa en gang at «Hvem som helst kan skrive resept. Det er alt det andre som er legekunst». Løge mente ikke å si at farmakoterapi alltid er enkelt, men at vi har et for sterkt fokus på legemidler - og for lite fokus på «alt det andre». Løges kloke ord reflekteres i Robin Holtedahls oversiktsartikkel om pregabalin ved fibromyalgi i dette nummer av Tidsskriftet (1).

Holtedahls budskap er saklig og velfundert: Pregabalins «dokumentasjon» ved fibromyalgi begrenser seg til et fătall studier i regi av produsenten Pfizer. De positive effektene er i beste fall små, og for et flertall pasienter uten særlig betydning. Bivirkningene underkommuniseres systematisk, og nettoresultatet er alt annet enn åpenbart. Likevel formidles pregabalins indikasjoner ved fibromyalgi som en slags verbal versjon av den gamle historien om Tordenskjolds soldater - $\mathrm{i}$ en lang serie oversiktsartikler, ofte ført i pennen av Pfizers håndgangne menn. Lite virksom farmakoterapi fortrenger annen behandling som vi vet virker (1).

Pregabalin har tre godkjente indikasjoner; nevropatisk smerte, tilleggsbehandling ved noen epilepsiformer og generalisert angstlidelse. Når jeg googler «nevropatisk smerte», er de tre første treffene (inklusive nettadressen nevropatisksmerte.no!) Pfizer-domener som informerer om pregabalins fortreffelighet. Påstandene er vanskelige å verifisere; bl.a. savnes sammenliknende studier med pregabalin og annen farmakoterapi på denne indikasjonen (2). Mer uavhengige kilder gir helt andre opplysninger enn Pfizer: Pregabalin er «en smule mer effektivt enn placebo» (3), underlegent både trisykliske antidepressiver og noen eldre antiepileptika når det gjelder effekt $(4,5)$, en versting på bivirkningssiden (5) og har misbrukspotensial (6). Preparatets plass i behandlingen av nevropatiske smerter fremstår på en slik bakgrunn som alt annet enn kunnskapsbasert.

Fremdeles ser vi at studier ikke publiseres. I pregabalins tilfelle er tre av seks fibromyalgistudier publisert i tidsskrifter med fagfellevurdering, mens de øvrige tre enten foreligger i kortversjoner eller ikke i det hele tatt (1). Dette betyr at vi mangler grunnlag til å vurdere utfall og effekter hos rundt halvparten av personene som har deltatt i Pfizers kliniske studier av pregabalin ved fibromyalgi. Dette er både et brudd på grunnleggende forskningsetikk og en mulig kilde til feilslutninger mht. pregabalins yteevne. Denne type problemer er dessverre ikke Pfizer-spesifikke, noe publiseringshistorien til nyere antidepressiver kan eksemplifisere: Allerede i 2003 rapporterte svenske forskere selektiv publisering av effektstudier med antidepressiver (7). Nyere data fra USA viser at $97 \%$ av de positive og $9 \%$ av de negative studiene blir publisert (8). Dette har naturligvis følger for hvordan dokumentasjonsgrunnlaget oppfattes og tolkes: Da Kirsch og medarbeidere med en lovforskrift i ryggen endelig fikk tilgang til det komplette kunnskapstilfanget om nyere antidepressiver hos de amerikanske legemiddelmyndighetene, viste metaanalysen effekter som for de aller fleste ikke lar seg skille fra placebo (9).

Et annet hovedproblem er at de studiene som publiseres, kan være konstruert på en måte som i utgangspunktet favoriserer den nye intervensjonen. Holtedahl beskriver hvordan man i to av de tre publiserte pregabalinstudiene hadde ekskludert pasienter som enten ikke responderte på gabapentin (som har samme virkeprinsipp som pregabalin) eller som responderte godt på placebo (1). Slike grep, som gjør at pregabalin kommer bedre ut enn ellers, er også utbredt hos andre enn Pfizer: I en metaanalyse om effekten av ikke-steroide antiinflammatoriske midler (NSAID) ved gonartrose så vi hvordan man ved å stille krav om symptomforverring etter seponering av forhåndsbrukt middel befolket terapiarmene i studiene med NSAIDrespondere. Dette førte til at den smertestillende effekten av disse midlene fremsto som mye bedre enn i (mindretallet av) studier uten denne kreative seleksjonsprosedyren (10).

Kontroversene i kjølvannet av slikt blir gjerne fremstilt som ideologiske meningsbrytninger, hvor forskere med grunnleggende mistro til farmasøytisk industri kives med aktører underlagt det private næringslivs normer og regler. En slik tilnærmingsmåte er både uhensiktsmessig og misvisende: Vi har i dag etablerte, etterprøvbare og omforente kvalitetskriterier for hvordan kliniske studier skal gjennomføres og rapporteres. Når forskningen - slik vi her har sett noen eksempler på - ikke holder mål, skal dette ikke innby til føleri og synsing; det er objektivt klanderverdig.

Den tidligere NEJM-redaktøren Marcia Angell har - med direkte referanse til den farmasøytiske industrien - stilt det retoriske spørsmålet «Hva gjør en gorilla på $400 \mathrm{~kg}$ ?» Hun besvarer spørsmålet selv; den digre gorillaen gjør naturligvis akkurat hva den vil (11). Uansett hva vi måtte ønske, må vi alle forholde oss til den farmasøytiske industri og dens markedskraft som en sentral premissleverandør i legemiddelspørsmål. Fravær av faglighet, troverdighet og tillit ødelegger dette forholdet.

\section{Lars Slørdal}

lars.slordal@ntnu.no

Lars Slørdal (f. 1955) er professor i farmakologi ved Norges teknisk-naturvitenskapelige universitet og overlege i bistilling ved Avdeling for klinisk farmakologi ved St. Olavs hospital, Trondheim

Oppgitte interessekonflikter: Ingen

\section{Litteratur}

1. Holtedahl R. Tvilsom dokumentasjon av effekten av pregabalin mot fibromyalgi. Tidsskr Nor Legeforen 2010: 130: 1032-6.

2. Quilici S, Chancellor J, Löthgren M et al. Meta-analysis of duloxetine vs. pregabalin and gabapentin in the treatment of diabetic peripheral neuropathic pain. BMC Neurology 2009; 9: 6-19.

3. Prescrire editorial staff. Pregabalin: very similar to gabapentin. Prescrire International 2005; 14: 203-6.

4. Freynhagen R, Bennett MI. Diagnosis and management of neuropathic pain. BMJ 2009; 339: $391-5$

5. Wong M, Chung JWY, Wong TKS. Effects of treatments for symptoms of painful diabetic neuropathy: systematic review. BMJ 2007: 335: 87-96.

6. Chalabianloo F, Schjøtt J. Pregabalin og misbrukspotensial. Tidsskr Nor Legeforen 2009; 129: 186-7

7. Mellander H, Ahlqvist-Rastad J, Meijer $G$ et al. Evidence b(i)ased medicine selective reporting from studies sponsored by pharmaceutical industry: review of studies in new drug applications. BMJ 2003: 326: 1171-5.

8. Turner EH, Matthews AM, Linardatos E et al. Selective publication of antidepressant trials and its influence on apparent efficacy. NEJM 2008; 358: 252-60.

9. Kirsch I, Deacon BJ, Huedo-Medina TB et al. Initial severity and antidepressant benefits: a meta-analysis of data submitted to the Food and Drug Administration. PloS Med 2008; 5: 260-8.

10. Bjordal JM, Ljunggren AE, Klovning A et al. Non-steroidal anti-inflammatory drugs, including cyclo-oxygenase-2 inhibitors, in osteoarthritic knee pain: metaanalysis of randomised placebo controlled trials. BMJ 2004; 329: 1317-22.

11. Angell M. The truth about the drug companies. How they deceive us and what to do about it. New York: Random House, 2004 